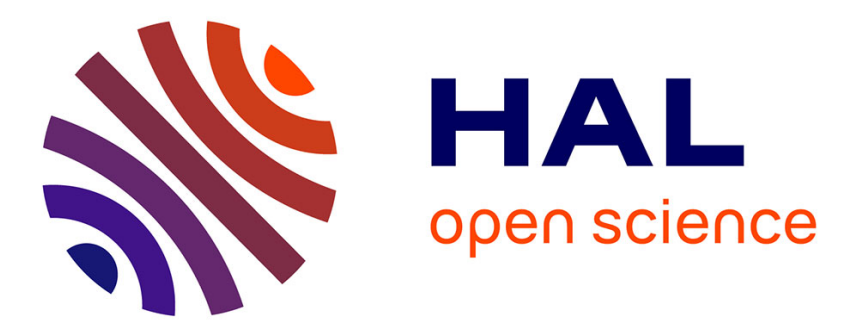

\title{
Antibiotic resistance among bacterial pathogens in Central Africa: a review of the published literature between 1955 and 2008
}

\author{
E. Vlieghe, M.F. Phoba, J.J. Muyembe Tamfun, J. Jacobs
}

\section{- To cite this version:}

E. Vlieghe, M.F. Phoba, J.J. Muyembe Tamfun, J. Jacobs. Antibiotic resistance among bacterial pathogens in Central Africa: a review of the published literature between 1955 and 2008. International Journal of Antimicrobial Agents, 2009, 34 (4), pp.295. 10.1016/j.ijantimicag.2009.04.015 . hal00556348

\section{HAL Id: hal-00556348 \\ https://hal.science/hal-00556348}

Submitted on 16 Jan 2011

HAL is a multi-disciplinary open access archive for the deposit and dissemination of scientific research documents, whether they are published or not. The documents may come from teaching and research institutions in France or abroad, or from public or private research centers.
L'archive ouverte pluridisciplinaire HAL, est destinée au dépôt et à la diffusion de documents scientifiques de niveau recherche, publiés ou non, émanant des établissements d'enseignement et de recherche français ou étrangers, des laboratoires publics ou privés. 


\section{Accepted Manuscript}

Title: Antibiotic resistance among bacterial pathogens in Central Africa: a review of the published literature between 1955 and 2008

Authors: E. Vlieghe, M.F. Phoba, J.J. Muyembe Tamfun, J. Jacobs

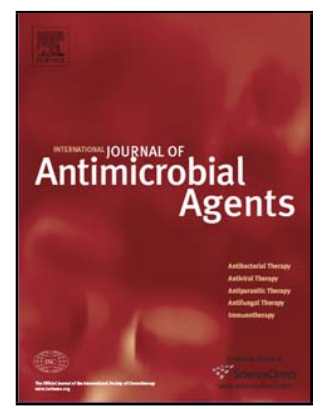

PII: S0924-8579(09)00217-9

DOI:

Reference: doi:10.1016/j.ijantimicag.2009.04.015

To appear in: International Journal of Antimicrobial Agents

Received date: $\quad$ 2-2-2009

Revised date: 29-4-2009

Accepted date: $\quad 30-4-2009$

Please cite this article as: Vlieghe E, Phoba MF, Tamfun JJM, Jacobs J, Antibiotic resistance among bacterial pathogens in Central Africa: a review of the published literature between 1955 and 2008, International Journal of Antimicrobial Agents (2008), doi:10.1016/j.ijantimicag.2009.04.015

This is a PDF file of an unedited manuscript that has been accepted for publication. As a service to our customers we are providing this early version of the manuscript. The manuscript will undergo copyediting, typesetting, and review of the resulting proof before it is published in its final form. Please note that during the production process errors may be discovered which could affect the content, and all legal disclaimers that apply to the journal pertain. 


\section{Antibiotic resistance among bacterial pathogens in Central Africa: a review of the published literature between 1955 and 2008}

E. Vlieghe ${ }^{a, *}$, M.F. Phoba $^{\text {b }}$, J.J. Muyembe Tamfun ${ }^{\text {b }}$, J. Jacobs ${ }^{a}$

${ }^{a}$ Department of Clinical Sciences, Institute of Tropical Medicine, Nationalestraat 155, 2000 Antwerp, Belgium

${ }^{\mathrm{b}}$ Institut National de Recherche Biomédicale (INRB), Avenue de la Démocratie (ex Huileries), Kinshasa/Gombe B.P. 1197 Kinshasa 1, Democratic Republic of the Congo

\section{ARTICLE INFO}

Article history:

Received 2 February 2009

Accepted 30 April 2009

Keywords:

Drug resistance

Antibacterial agents

Central Africa

Surveillance review

* Corresponding author. Tel.: +32 382139 77/+32 475821583.

E-mail address: Evlieghe@itg.be (E. Vlieghe). 


\section{ABSTRACT}

A systematic review of the published literature on bacterial resistance in Central Africa between 1955 and 2008 was performed. Eighty-three publications from seven countries were retrieved, the majority presenting data on enteric and other Gramnegative pathogens. Despite methodological limitations in many studies, alarming resistance rates are noted in nearly all pathogens. Of special concern are multidrug resistance in Shigella and Salmonella spp. and the emergence of meticillin-resistant Staphylococcus aureus, high-level penicillin-resistant Streptococcus pneumoniae and extended-spectrum $\beta$-lactamases among Gram-negative pathogens. These findings make clear that the Central African region shares the worldwide trend of increasing antimicrobial resistance and is in urgent need of sound surveillance based on competent and affordable microbiology to provide clear data on antimicrobial resistance. These data could enable redaction of local treatment guidelines and fuel national and regional policies to contain antimicrobial resistance. 


\section{Introduction}

Developing countries face substantial problems of antimicrobial resistance.

Contributing factors include those involving the public (e.g. self-medication), prescriber (e.g. misinformation, absence of diagnostic tools) and dispenser (e.g. over-the-counter use, inadequate storage, use of expired drugs) [1,2]. Correct knowledge of actual resistance patterns is the cornerstone of successful containment of antimicrobial resistance. Good quality data are available from more affluent and transitory countries (e.g. in Latin America [3] and Asia [4,5]), but there is little information available from many countries in sub-Saharan Africa, especially from the Central African region. Thus, a systematic review was performed to compile the available information on bacterial resistance in this region.

\section{Materials and methods}

The region of Central Africa was considered as described in the United Nation's geoscheme [6], comprising the countries Cameroon, Chad, Gabon, São Tomé e Príncipe, Congo-Brazzaville, Democratic Republic of the Congo (DRC) (formerly Zaire), the Central African Republic (CAR), Angola and Equatorial Guinea. The study focused on bacterial pathogens, excluding Mycobacterium tuberculosis and agents causing sexually transmitted infections. Relevant literature was identified from the PubMed online database of the US National Library of Medicine. Search terms included 'bacterial resistance', 'antibiotic use', 'antimicrobial resistance' and 'bacterial surveillance' combined with the different countries and 'Central Africa'. Bibliographies of all relevant papers were searched to identify further papers. A similar search was also performed in the Medical Literature on Central Africa database at the library of 
the Institute of Tropical Medicine Antwerp (Belgium). In addition, relevant websites providing medical literature for use in developing countries were accessed.

All articles were reviewed by at least two authors. Only publications listing original data on bacterial resistance in humans were included. Studies were further assessed for design, setting, demographic data and microbiological methodology. Studies reporting archived results of susceptibility testing as part of routine clinical care were categorised as retrospective laboratory studies, and studies addressing a particular clinical condition (e.g. meningitis) were termed clinical studies. Surveillance studies were considered as those complying with the World Health Organization (WHO) surveillance standards [7], i.e. studies focusing on a particular pathogen carried out by a reference laboratory and/or a network of sentinel laboratories.

The WHO criterion of $48 \mathrm{~h}$ hospital admission was used for the distinction between community- and hospital-acquired (nosocomial) infections. If no data on duration of hospital admission were mentioned, the categories as mentioned by the authors were used.

Relevant microorganisms and antibiotics were primarily those listed by the WHO Surveillance Standards. Key organisms included Staphylococcus aureus, Streptococcus pneumoniae, the enteric pathogens (i.e. Campylobacter, Vibrio, Shigella and Salmonella spp.), Klebsiella pneumoniae, Escherichia coli, Pseudomonas aeruginosa, Haemophilus influenzae and Neisseria meningitidis. Antibiotics included the first-line antibiotics [benzyl penicillin, ampicillin and/or amoxicillin, oxacillin, trimethoprim/sulfamethoxazole (SXT), tetracycline, 
chloramphenicol, erythromycin, clindamycin and nalidixic acid] as well as representatives of the different generations of cephalosporins, aminoglycosides and fluoroquinolones. Unless otherwise stated, intermediate-resistant strains were grouped together with resistant strains. Mean resistance rates for data from different studies combined were calculated by dividing the sum of all resistant organisms (nominator) over the sum of all organisms tested (denominator). The minimum number of isolates per species for separate reporting was set at 10 , in line with the European Society of Clinical Microbiology and Infectious Diseases Study Group for Antimicrobial Resistance Surveillance (ESGARS) [8] and the Clinical and Laboratory Standards Institute (CLSI) [9] recommendations.

\section{Overview of study design, study setting and microbiological methods}

A total of 173 articles published between 1954 and 2008 were retrieved, of which 83 were eligible for inclusion in the review. The majority of these publications originated from DRC ( $n=37$, including 3 publications on data from Rwandese and Congolese patients during cross-border epidemics), followed by CAR $(n=15)$ and Cameroon ( $n$ = 14) $($ Fig. 1). More than one-half $(43 / 83 ; 51.8 \%)$ of the studies were surveillance studies, the majority of them studying enteric pathogens (30/43; 69.8\%) in DRC $(21 / 43 ; 48.8 \%)$. Another large part of the studies $(34 / 83 ; 41.0 \%)$ were retrospective laboratory studies or short-term clinical studies.

Most studies (50/83; 60.2\%) were carried out in urban settings. Of the rural studies, nearly three-quarters $(18 / 25 ; 72.0 \%)$ were performed in DCR, mainly on Shigella spp. 
and other enteric pathogens. The median duration of studies was 16.5 months (range $1-133$ months).

Among the studies that mentioned the patients' age groups, there was a predominance of studies on or involving children (40/50; $80.0 \%)$. The origin of infection was clearly retrievable in 56 studies, most of which (52/56; 92.9\%) described community-acquired infections, and only 4 studies explicitly addressed nosocomial infections [10-13]. Co-morbidity was stated in only five studies, mainly human immunodeficiency virus (HIV) and sickle cell anaemia [14-18].

A research or reference laboratory was involved in 58 (69.9\%) of the 83 studies, the vast majority of which addressed Vibrio cholerae and Shigella spp. Faeces were the most frequently studied clinical sample $(42 / 83 ; 50.6 \%)$, followed by blood (19/83; $22.9 \%)$ and cerebrospinal fluid (CSF) (18/83; $21.7 \%)$.

The methodologies of antibiotic susceptibility testing were described in 71 studies (85.5\%), including mainly the disk diffusion method (60/83; $72.3 \%)$ and the agar dilution method $(17 / 83 ; 20.5 \%)$. Broth dilution and Etest were performed in four and three studies, respectively. Batch testing with the agar dilution method was mainly used by reference laboratories assessing outbreaks of $V$. cholerae and Shigella spp. Only $31(37.3 \%)$ of 83 studies mentioned a reference method such as the KirbyBauer method (or its modifications) or the methods of the CLSI [19] or the French Society for Microbiology [20]. Use of control stains and participation in external quality programmes were mentioned in only 14 and 3 studies, respectively. Only 5 
(6.0\%) of 83 studies considered only one sample per patient and per episode as recommended [21].

\section{Resistance rates for different species}

\subsection{Gram-positive bacteria}

\subsubsection{Staphylococcus aureus (Table 1) [10,17,22-28]}

Resistance data for $S$. aureus were reported in nine studies, including three surveillance studies and six clinical studies from urban hospitals. Although a wide range of samples (pus, wounds, urine and CSF) was addressed from mixed origins (community, nosocomial), only one study considered blood cultures [24]. Of note is that in some studies panels for susceptibility testing were not in accordance with WHO surveillance standards, e.g. did not contain oxacillin or an equivalent antibiotic [24].

As can be seen in Table 1, the presence of meticillin-resistant S. aureus (MRSA) was examined in six studies. Kesah et al. [10] surveyed MRSA prevalence in eight African countries, including Cameroon as the only country from Central Africa. They found MRSA in 27 (21.3\%) of 127 Cameronese samples. This was among the top three highest prevalence figures in the study, only after Kenya $(38 / 137 ; 27.7 \%)$ and Nigeria (42/142; 29.6\%). A recent Congolese study [26] among nasal staphylococcal carriers reported an MRSA prevalence of $63.1 \%, 66.7 \%$ and $23.3 \%$ in hospitalised patients, hospital staff and outpatients, respectively. 


\subsubsection{Streptococcus pneumoniae (Table 2) [14,15,22,28-35]}

Data were found in 11 studies conducted between 1990 and 2008, mainly in urban children. Clinical samples were predominantly from CSF (8/11; 72.7\%); one study described blood cultures isolates [15]. Another two studies described surveillance in nasopharyngeal isolates from healthy and sick children [31,32].

Overall, low numbers of isolates were studied (range 7-272; median 34); only 4/11 studies tested more than 50 isolates. Penicillin was tested in eight studies, of which only four distinguished between 'intermediate' and 'high-level' resistance. Although rates of intermediate resistance to penicillin were reported up to $67.0 \%$, high-level resistance remained $<6 \%$ overall. Notable resistance rates were those for SXT (up to $69 \%$ ) and chloramphenicol (up to $60 \%$ ).

\subsection{Gram-negative bacteria}

\subsubsection{Shigella spp. [16,36-53]}

Eighteen studies were found, mainly from rural DRC $(12 / 18 ; 66.7 \%)$ and published between 1955 and 2006. Two-thirds reported on outbreak investigations, and Shigella dysenteriae type 1 was the predominant serotype (15/18 studies). Occasionally, samples from blood, CSF or pus were included [16,49]. Multiresistant Shigella isolates emerged in the late 1970s. A survey from Kinshasa (DRC) in 1964 demonstrated resistance to two or more antibiotics in $10 \%$ of 368 strains. In 1979, spread of a clone with plasmid-mediated resistance to ampicillin, chloramphenicol, streptomycin, sulphonamides and tetracycline was noted in Eastern Zaire (now DRC) $[37,41,47,48]$ and 2 years later $75 \%$ of the strains showed additional trimethoprim 
resistance through a newly acquired plasmid. Dysentery treatment consequently shifted to nalidixic acid, to which resistance developed in May 1982, disappearing after the discontinuation of mass treatment with nalidixic acid [43]. Several reports described the large outbreak of $S$. dysenteriae dysentery among Rwandese refugees after the 1994 civil war $[36,40,42,52]$, reporting similar patterns of multidrug resistance including nalidixic acid and trimethoprim, leaving the newer fluoroquinolones as a treatment option. Bercion et al. [38] and Cunin et al. [44] described similar outbreaks in CAR and Cameroon, respectively. Even outside the epidemic context, the prevalence of multidrug-resistant strains was found to be $>50 \%$ in recent reports from Kinshasa (DRC) [49] and Bangui (CAR) [53].

\subsubsection{Salmonella spp.}

\subsubsection{Salmonella enterica serovar Typhi $[16,18,45,49,54-62]$ (Table 3)}

Thirteen studies between 1973 and 2005 addressed S. Typhi, mainly in urban settings in DRC and Gabon (10/13; 76.9\%). Six of them were surveillance studies [45,49,54,60-62], of which five were conducted in DRC. Isolates were recovered from blood and faeces. Although mean resistance rates to amoxicillin, chloramphenicol and SXT were relatively low, there was a steeply increasing upward trend towards $50 \%$ resistance rates since the mid 1990s. Overall susceptibility for fluoroquinolones remained high. Only a single study [60] tested resistance for nalidixic acid as a predictor for fluoroquinolone resistance: all 37 samples were sensitive. Combined resistance was described in at least three studies. In a paediatric bacteraemia study in the DRC, Kariuki et al. [60] found resistance to five or more first-line antibiotics in $>95 \%$ of the isolates. 


\subsubsection{Non-typhoid Salmonella (NTS) $[23,24,28,45,49,54,59,61-66]$ (Table 4)}

The general study characteristics were similar to those reporting on $S$. Typhi, with five studies also addressing nosocomial infections. High mean resistance rates were noted for ampicillin (63.0\%), chloramphenicol (42.9\%) and the fluoroquinolones (16.8\%). Resistance to SXT was relatively low (14.6\%) and no resistance was noted to cefotaxime. Unlike $S$.Typhi, there was no clear temporal trend, except for SXT and the fluoroquinolones to which resistance emerged from 1999 onwards.

Multiresistance was reported frequently. In a 1973 study of a hospital outbreak in DRC, Kashemwa et al. [45] noted $24 \%$ of all NTS isolates to have combined resistance to ampicillin, streptomycin, kanamycin, tetracycline, chloramphenicol and sulfamethoxazole. Also in DRC, in 1977 Muyembe et al. [62] observed multiresistance in $76 \%$ of 1070 NTS isolates, of which $>90 \%$ were co-resistant to at least five commonly used antibiotics. In a 1993 Congolese bacteraemia study, multiresistance was noted in $30 \%$ of all NTS; $90 \%$ of isolates were co-resistant to ampicillin, chloramphenicol, tetracycline, streptomycin, sulphonamides, streptomycin and SXT [64]. Similar findings were described in Bangui (CAR) [66].

\subsubsection{Vibrio cholerae $[40,42,67-75]$}

Eleven reports from nearly all countries in the region were available. Most were published in the second half of the 1990s, often describing outbreaks among refugees, all by $V$. cholerae $\mathrm{O} 1 \mathrm{EI}$ Tor. Three studies from Chad, Cameroon and DRC noted little or no resistance $[70,73,75]$. However, extensive and multidrug resistance was described from outbreaks in DRC (1995-1997) with strains resistant to first-line drugs including ampicillin, tetracycline, doxycycline, SXT, nalidixic acid 
and chloramphenicol. In the same period, similar findings were reported from neighbouring Angola [67,72,74]. Of nine studies testing ampicillin, seven showed high ( $\geq 84 \%)$ rates of resistance. For tetracycline and chloramphenicol, four of eight studies revealed very high (>90\%) resistance rates. Isolates were resistant to sulphonamides or SXT in six and five of eight studies, respectively.

\subsubsection{Escherichia coli (Table 5) [23,24,25,44,76-85]}

Most data on E. coli were retrieved from clinical or laboratory archives, predominantly from urine and faeces, and rarely from blood or pus. Two publications focused on enteroaggregative E. coli in children [78,79], and Cunin et al. [44] described a dysentery outbreak with E. coli 0157 in Cameroon. Overall, broad ranges of antibiotics were used for susceptibility testing and several inappropriate drugs (e.g. clindamycin, erythromycin, tetracycline and doxycycline) were tested $[23,25]$. The reported and mean resistance rates were very high for all commonly used antibiotics but also for amoxicillin/clavulanic acid and first-generation cephalosporins. Resistance remained much lower for aminoglycosides, fluoroquinolones and nitrofurantoin, and no resistance to third-generation cephalosporins was reported by the cited authors with the exception of Gangoue-Pieboji et al. [76]. Data on multiresistance were recorded from DRC and Gabon by Jalaluddin et al. [78] and Burchard and Wolff [25], respectively. The former described 10 different resistance patterns, with the most frequent pattern being combined resistance to tetracycline, ampicillin, chloramphenicol, streptomycin and chloramphenicol. Similarly, $26.7 \%$ of 86 isolates in the latter study combined resistance to ampicillin with doxycycline, SXT and chloramphenicol. 


\subsubsection{Klebsiella spp. (Table 6) [11,23,24,25,33,76,80,81,83-85]}

Eleven authors described resistance patterns in Klebsiella spp. from a variety of samples (blood, urine, respiratory, pus and faeces). Similar to E. coli, the source of information was archived clinical or laboratory data in large urban centres from a heterogeneous group of patients, covering the period 1976-2006. High resistance rates were noted for amoxicillin/clavulanic acid (52.9\%), chloramphenicol (43.2\%), gentamicin (47.7\%) and SXT (80.3\%). For fluoroquinolones and third-generation cephalosporins, resistance is emerging ( $7.4 \%$ and $3.3 \%$, respectively). Susceptibility to carbapenems remained preserved. Ndip et al. (Cameroon) [11] and Burchard and Wolff (Gabon) [25] described multiresistance for (combinations of) ampicillin, doxycycline, SXT and chloramphenicol at $77.3 \%$ and $33 \%$, respectively.

\subsubsection{Presence of extended-spectrum $\beta$-lactamase (ESBL)}

Two authors focused on the presence of ESBLs in Gram-negative bacteria $[12,86,87]$. Both used the double-disk method and studied miscellaneous Enterobacteriaceae, mostly E. coli and Klebsiella spp. Frank et al. in Bangui (CAR) [87] described an ESBL prevalence of $4 \%$ among 450 Enterobacteriaceae isolates. In addition, nearly $65 \%$ of the ESBL-producing isolates showed combined resistance to aminoglycosides, tetracycline and fluoroquinolones. In Cameroon, GangouéPieboji et al. [12] observed the presence of ESBL in 13 (14.3\%) of $91 \mathrm{E}$. coli isolates and in $12(18.8 \%)$ of 64 Klebsiella spp. tested. A large part (47-84\%) of these isolates were of nosocomial origin. Most of them carried CTX-M-15 and SVH-12 and to a lesser extent CTX-M-3 and SHV 2a as the responsible gene. 


\subsubsection{Pseudomonas aeruginosa (Table 7) $[25,76,88,89]$}

Four studies described resistance data from urine, pus and respiratory tract samples and the hospital environment; they included few invasive (blood) samples. At least one study included nosocomial samples [88]. Resistance was not limited to gentamicin and piperacillin but also extended to fluoroquinolones and ceftazidime (15.5\% and $32.2 \%$ mean resistance rates, respectively). Resistance to carbapenems was looked for in a single study and remained low (6\%).

Multiresistance to clinically relevant antibiotics was assessed by Ndip et al. in Cameroon [88], who noted combined resistance to at least two antibiotics in all strains. Multidrug resistance to at least four antibiotics was as frequent as $41.2 \%$.

\subsection{Gram-negative cocci}

\subsubsection{Neisseria meningitidis $[14,28,29,34,90-92]$}

Data between 1968 and 2008 were found, mainly from countries near to the meningitis belt (i.e. Chad, Cameroon). Unlike most other pathogens studied, resistance to all commonly used antibiotics was not demonstrated or was very low, although minimal inhibitory concentration (MIC) values were not reported and numbers studied were low. Most authors reported resistance data for penicillin [mean resistance rate 1/76 (1.3\%)] and chloramphenicol [mean resistance rate 2/91 (2.2\%)]. Some authors gave also resistance figures for rifampicin (no resistance noted in seven isolates tested) $[91,92]$ and third-generation cephalosporins $(2 / 61 ; 3.3 \%)$ $[29,92]$. 


\subsection{Miscellaneous}

4.4.1. Haemophilus influenzae [22,28,29,32,34,35,93] and Moraxella catarrhalis [94]

Seven studies reported on $H$. influenzae strains, with the following mean resistance rates: ampicillin 34.3\% (68/198); third-generation cephalosporins 6.2\% (6/97); chloramphenicol 11.6\% (23/198); gentamicin 41.3\% (19/46); and SXT 32.7\% (37/113). Screening of respiratory samples from 19 rural Angolan children for the presence of $\beta$-lactamase in $M$. catarrhalis revealed a prevalence of $89.5 \%$.

\section{Discussion and conclusion}

In this study we reviewed published data on bacterial resistance in Central Africa. There are several limitations to this study. First, the exploration of data was problematic. For logistical reasons we did not search the 'grey' literature. Owing to historical collaboration and institutional and private networks, some countries such as DRC and Cameroon were most represented; for Equatorial Guinea and São Tomé e Príncipe, no usable data were found. Second, at present we did not consider agents of mycobacterial and sexually transmitted infections.

Regarding the retrieved studies, several issues regarding epidemiological and microbiological methods must be mentioned. First, it should be noted that few studies were designed as prospective surveillance studies. Furthermore, many studies performed susceptibility testing on only a fraction of isolates recovered, and few studies mentioned selection of a single strain per patient and episode. Enteric pathogens (Shigella, Salmonella, Vibrio spp.) were far more represented than the other key pathogens. Only a few reports $[10,13]$ addressed genuine nosocomial 
and/or invasive isolates, which are notorious for their antimicrobial resistance even in developing countries [95]. On the other hand, urine, respiratory and wound samples from clinical studies might include a selection of difficult-to-treat infections and hence possibly present a bias toward resistant strains [96]. With regard to microbiological methods, few studies mentioned application of quality assurance in identification and susceptibility testing, and quantitative susceptibility data (e.g. MICs or inhibition diameters) were only rarely available. Likewise, distinction between intermediate and high-level resistance in case of $S$. pneumoniae was not always reported, and in several studies panels of antibiotics selected for testing were heterogeneous (making comparisons difficult) or even inappropriate.

Despite the limitations, several interesting observations can be made. The studies on Shigella and Vibrio spp. give a good impression on the evolution of their epidemiology and resistance patterns, particularly in the eastern part of DRC. The resistance patterns of Shigella spp. are in line with those found in the neighbouring countries of Rwanda and Burundi, which have historically been investigated together with DRC [97-101]. Given the fact that these pathogens often act in outbreaks among weakened people, these very extensive resistance patterns urge for very tight surveillance and frequently updated treatment policies in case of outbreaks.

Resistance data on the other pathogens were much more scarce and heterogeneous and displayed wide ranges in resistance rates. Nevertheless, worrying trends are to be noted, especially among Gram-negative enteric organisms. The actual multiresistance patterns of NTS and the emerging resistance trends among $S$. Typhi isolates are of concern, as many of the widely used cheap first-line antibiotics are no 
longer active for the treatment of these endemic organisms. In particular, emerging fluoroquinolone resistance is of concern. With regard to other Enterobacteriaceae and non-fermentative organisms such as $P$. aeruginosa, only estimations of antimicrobial resistance patterns can be given, but it is clear that multiresistant isolates including those with ESBL are present.

In Gram-positive pathogens data are even more scarce and heterogeneous. The real prevalence of colonising and invasive MRSA infections in this region remains unclear. The problem is under-screened and possibly underestimated.

Penicillin resistance in $S$. pneumoniae was more consistently tested but was rarely expressed as intermediate or high-level resistance despite its relevance for future empirical antibiotic guidelines. High-level resistance was seen rarely but an increase in intermediate-level resistance was noted.

The present data should be a matter of concern and increased awareness, especially in view of their entanglement with other major health problems highly prevalent in the Central African region such as HIV/acquired immune deficiency syndrome (AIDS), tuberculosis, malnutrition and malaria. Bacterial infections often coincide or complicate the course of other health problems. Shifts in antibiotic use for one infection can jeopardise treatment options for another [102].

Therefore, there is need for genuine and integrated surveillance. Bacteriology as a diagnostic tool in individual patient management is probably not cost effective, but cohort-based surveys [103] studying a limited set of key pathogens in selected 
locations, with limited duration and repeated over time, may provide valuable information for the redaction and adaptation of standard treatment guidelines. Prerequisites for any type of laboratory surveillance are the implementation of quality-assured procedures and the availability of culture media, reagents and control strains of correct quality and at a reasonable cost. Most important, competent and dedicated laboratory staff collaborating closely with the medical and nursing staff are needed. Partnerships with laboratories in resource-rich countries [104] may be helpful for local capacity building through teaching, providing feedback and performing more expensive or technically complex investigations on selected strains.

In conclusion, although the present data only give a glimpse of the antimicrobial resistance rates of bacteria in Central Africa, it is clear that this region shares the worldwide trend of increasing antimicrobial resistance. Sound surveillance based on competent and affordable microbiology is required to provide clear data on antimicrobial resistance, which in turn can enable redaction of local treatment guidelines and fuel national and regional policies to contain antimicrobial resistance.

Authors' contributions: EV and JJ performed the research, retrieval and assessment of English language literature, and analysed the data; MFP performed the research, retrieval and assessment of French language literature, and performed analysis of the English literature. All authors contributed to the revision of the results and the discussion.

Acknowledgments: The authors wish to thank Diane Stessens and Lies Huyskens for their assistance. 
Funding: None.

Competing interests: None declared.

Ethical approval: Not required. 


\section{References}

[1] Byarugaba DK. A view on antimicrobial resistance in developing countries and responsible risk factors. Int J Antimicrob Agents 2004;24:105-10.

[2] Okeke IN, Lamikanra A, Edelman R. Socioeconomic and behavioral factors leading to acquired bacterial resistance to antibiotics in developing countries. Emerg Infect Dis 1999;5:18-27.

[3] Sader HS, Jones RN, Gales AC, Silva JB, Pignatari AC; SENTRY Participants Group (Latin America). SENTRY antimicrobial surveillance program report: Latin American and Brazilian results for 1997 through 2001. Braz J Infect Dis 2004;8:25-79.

[4] Song JH, Chang HH, Suh JY, Ko KS, Jung SI, Oh WS, et al. Macrolide resistance and genotypic characterization of Streptococcus pneumoniae in Asian countries: a study of the Asian Network for Surveillance of Resistant Pathogens (ANSORP). J Antimicrob Chemother 2004;53:457-63.

[5] Bell J, Turnidge J. SENTRY Antimicrobial Surveillance Program Asia-Pacific region and South Africa. Commun Dis Intell 2003;27(Suppl):S61-6.

[6] United Nations Statistics Division. Standard country and area codes classification (M49). http://unstats.un.org/unsd/methods/m49/m49regin.htm [accessed 7 May 2009].

[7] World Health Organization. Surveillance standards for antimicrobial resistance. Geneva: WHO; 2002. WHO/CDS/CSR/DRS/2001.5. http://www.who.int/drugresistance/publications/WHO_CDS_CSR_DRS_2001_5/e $\mathrm{n} /$ [accessed 7 May 2009]. 
[8] Cornaglia G, Hryniewicz W, Jarlier V, Kahlmeter G, Mittermayer H, Stratchounski L, et al. European recommendations for antimicrobial resistance surveillance. Clin Microbiol Infect 2004;10:349-83.

[9] Clinical and Laboratory Standards Institute. Principles and procedures for blood cultures; approved guideline. Document M47-A. Wayne, PA: CLSI; 2007.

[10] Kesah C, Ben Redjeb S, Odugbemi TO, Boye CS, Dosso M, Ndinya Achola JO, et al. Prevalence of methicillin-resistant Staphylococcus aureus in eight African hospitals and Malta. Clin Microbiol Infect 2003;9:153-6.

[11] Ndip RN, Titanji VP, Akenji TN, Mutanga AM, Mbacham WF, Ndip LM. Antibiogram of Klebsiella pneumoniae isolates from Buea, Cameroon. Cent Afr J Med 2001;47:173-6.

[12] Gangoué-Pieboji J, Bedenic B, Koulla-Shiro S, Randegger C, Adiogo D, Ngassam P, et al. Extended-spectrum- $\beta$-lactamase-producing Enterobacteriaceae in Yaounde, Cameroon. J Clin Microbiol 2005;43:3273-7.

[13] Bercion R, Gaudeuille A, Mapouka PA, Behounde T, Guetahoun Y. Surgical site infection survey in the orthopaedic surgery department of the "Hôpital communautaire de Bangui," Central African Republic [in French]. Bull Soc Pathol Exot 2007;100:197-200.

[14] Bekondi C, Bernede C, Passone N, Minssart P, Kamalo C, Mbolidi D, et al. Primary and opportunistic pathogens associated with meningitis in adults in Bangui, Central African Republic, in relation to human immunodeficiency virus serostatus. Int J Infect Dis 2006;10:387-95.

[15] Kassa-Kelembho E, Mbolidi CD, Service YB, Morvan J, Minssart P. Bacteremia in adults admitted to the Department of Medicine of Bangui Community Hospital (Central African Republic). Acta Trop 2003;89:67-72. 
[16] Okome-Nkoumou M, Elsa NJ, Kombila M. Causes of adult acute bacterial diarrhea in an internal medicine department in Libreville, Gabon [in French]. Med Trop (Mars) 2001;61:143-7.

[17] Bileckot RR, Miakoundoba RC, Yala F. Microbiology and prognosis of septic arthritis in Brazzaville. Joint Bone Spine 2006;73:575-6.

[18] Okome-Nkoumou M, Ayo NE, Bekale J, Kombila M. Typhoid and paratyphoid fever in adults in the Internal Medicine Department at Libreville (Gabon). Sante 2000;10:205-9.

[19] World Health Organization. Basic laboratory procedures in clinical bacteriology. Geneva: WHO; 1991.

http://www.helid.desastres.net/gsdl2/tmp/export/who/who01e.pdf [accessed 7 May 2009].

[20] Soussy CJ, Carret G, Cavallo JD, Chardon H, Chidiac C, Choutet P, et al. Antibiogram Committee of the French Microbiology Society. Report 2000-2001 [in French]. Pathol Biol (Paris) 2000;48:832-71.

[21] Peterson LR, Brossette SE. Hunting health care-associated infections from the clinical microbiology laboratory: passive, active, and virtual surveillance. J Clin Microbiol 2002;40:1-4.

[22] Tetanye E, Yondo D, Bernard-Bonnin AC, Tchokoteu PF, Kago I, Ndayo M, et al. Initial treatment of bacterial meningitis in Yaounde, Cameroon: theoretical benefits of the ampicillin-chloramphenicol combination versus chloramphenicol alone. Ann Trop Paediatr 1990;10:285-91.

[23] Takaïsi K, Kandolo DK, Musema MG, Sadiki NH. Résistance aux antibiotiques des Entérobactéries et des Staphylococques isolés en milieu hospitalier de la ville de Kinshasa. Congo Médical 2003;3:1367-71. 
[24] Bahwere P, Levy J, Hennart P, Donnen P, Lomoyo W, Dramaix-Wilmet M, et al. Community-acquired bacteremia among hospitalized children in rural central Africa. Int J Infect Dis 2001;5:180-8.

[25] Burchard GD, Wolff T. Study of bacterial sensitivity in a Lambaréné hospital (Gabon) [in French]. Med Trop (Mars) 1985;45:265-9.

[26] Nyembwe KM, Manienga KJ, Manyebwa KJD, Mulumba MP, Verhaegen J, Myembe TJJ. Profil de la méthicillinorésistance de Staphylococcus à Kinshasa et implications dans l'hygiène hospitalière. Congo Médical 2004;3:1262-5.

[27] Delcour G. Staphylococci and antibiotics. Ann Soc Belg Med Trop (1920) 1954;34:407-16.

[28] Bercion R, Bobossi-Serengbe G, Gody JC, Beyam EN, Manirakiza A, Le Faou A. Acute bacterial meningitis at the 'Complexe Pédiatrique' of Bangui, Central African Republic. J Trop Pediatr 2008;54:125-8.

[29] Fonkoua MC, Cunin P, Sorlin P, Musi J, Martin PM. Bacterial meningitis in Yaounde (Cameroon) in 1999-2000. Bull Soc Pathol Exot 2001;94:300-3.

[30] Kokindombo PO, Nko'o AS, Ndjitoyap Ndam EC, Wouaffo NM, Tangam OT, Tietche $\mathrm{F}$, et al. Purulent meningitis due to Flavobacterium meningosepticum in Cameroonian children [in French]. Ann Pediatr (Paris) 1991;38:491-5.

[31] Mumba ND, Verhaegen J, Tshilolo L, Kabeya A, Kabulu AJ, Muyembe TJJ. Sérotypes et pharmacorésistance des pneumocoques isolés chez les porteurs sains: étude préliminaire. Congo Médical 2005;4:135-8.

[32] Ndoyo J. Antibiotic resistance among nasopharyngeal isolates of Streptococcus pneumoniae and Haemophilus influenzae-Bangui, Central African Republic, 1995. MMWR Morb Mortal Wkly Rep 1997;46:62-4. 
[33] Okome-Nkoumou M, Mahoumbou J, Ngaka-Safou D. Data on the etiology of bacterial infection in Libreville between 1992 and 1996 [in French]. Med Trop (Mars) 2004;64:102-3.

[34] Sile Mefo H, Sile H, Mbonda E, Fezeu R, Fonkoua D. Les meningitis purulentes de l'enfant au Nord-Cameroun: aspects épidemiologiques, diagnostics et évolutifs. Med Afr Noire 1999;46:83-6.

[35] Koko J, Dufillot D, Kani F, Seilhan C, Batsielili S, Gahouma D, et al. Antibiotic sensitivity of bacteria responsible for acute meningitis in children in Libreville (Gabon). Arch Pediatr 2002;9:445-6.

[36] Bitwe MR, Vandenberg O, Donnen Ph, Nsibu NC. Epidémies de dysentérie bacillaire dans la région de Lwiro au Sud-Kivu (1993-1994): étude de la chimiorésistance de Shigella aux antibiotiques. Congo Médical 2000;2:1003-6.

[37] Frost JA, Willshaw GA, Barclay EA, Rowe B, Lemmens P, Vandepitte J. Plasmid characterization of drug-resistant Shigella dysenteriae 1 from an epidemic in Central Africa. J Hyg (Lond) 1985;94:163-72.

[38] Bercion R, Demartin M, Recio C, Massamba PM, Frank T, Escriba JM, et al. Molecular epidemiology of multidrug-resistant Shigella dysenteriae type 1 causing dysentery outbreaks in Central African Republic, 2003-2004. Trans R Soc Trop Med Hyg 2006;100:1151-8.

[39] Ebright JR, Moore EC, Sanborn WR, Schaberg D, Kyle J, Ishida K. Epidemic Shiga bacillus dysentery in Central Africa. Am J Trop Med Hyg 1984;33:1192-7.

[40] Cavallo JD, Niel L, Talarmin A, Dubrous P. Antibiotic sensitivity to epidemic strains of Vibrio cholerae and Shigella dysenteriae 1 isolated in Rwandan refugee camps in Zaire [in French]. Med Trop (Mars) 1995;55:351-3. 
[41] Frost JA, Rowe B, Vandepitte J, Threlfall EJ. Plasmid characterisation in the investigation of an epidemic caused by multiply resistant Shigella dysenteriae type 1 in Central Africa. Lancet 1981;2:1074-6.

[42] Islam MS, Siddique AK, Salam A, Akram K, Majumdar RN, Zaman K, et al. Microbiological investigation of diarrhoea epidemics among Rwandan refugees in Zaire. Trans R Soc Trop Med Hyg 1995;89:506.

[43] Malengreau M, Molima-Kaba, Gillieaux M, de Feyter M, Kyele-Duibone, Mukolo-Ndjolo. Outbreak of Shigella dysentery in Eastern Zaire, 1980-1982. Ann Soc Belg Med Trop 1983;63:59-67.

[44] Cunin P, Tedjouka E, Germani Y, Ncharre C, Bercion R, Morvan J, et al. An epidemic of bloody diarrhea: Escherichia coli 0157 emerging in Cameroon? Emerg Infect Dis 1999;5:285-90.

[45] Kashemwa C, Isebaert A, Vieu JF, Vandepitte J. Shigella and Salmonella of the Kivu region (Zaire) [in French]. Ann Soc Belg Med Trop 1973;53:595-603.

[46] Omanga U, Muganga N, Kapepela M. Bacterial septicemias in children with homozygous sickle cell anemia. Analysis of 69 cases [in French]. Ann Pediatr (Paris) 1989;36:315-8.

[47] Frost JA, Rowe B, Vandepitte J. Acquisition of trimethoprim resistance in epidemic strain of Shigella dysenteriae type 1 from Zaire. Lancet 1982;1:963.

[48] World Health Organization. Shigellosis surveillance; drug resistant shiga strains. Wkly Epidemiol Rec 1983;12:87.

[49] Lunguya O, Asuni M, Mumba D, Mabwa L, Nsungu M, Manienga J, et al. Sérotypes et pharmacorésistance des Salmonella et Shigella à Kinshasa (19941999). Congo Médical 2005;4:227-33. 
[50] Vandepitte J, Gatti F. Shigellosis at Leopoldville. Bacteriologic and epidemiologic aspects [in French]. Ann Soc Belg Med Trop 1964;44:549-65.

[51] Verselder R, Courtois G, Imbos P. Bacillary dysentery in Stanleyville; clinical and epidemiological importance of the therapeutic resistance of certain Shigella cultures [in French]. Bull Soc Pathol Exot Filiales 1955;48:892-905.

[52] Milleliri JM, Soares JL, Signoret J, Bechen R, Lamarque D, Boutin JP, et al. Epidemic of bacillary dysentery in the Rwanda refugee camps of the Goma region (Zaire, North Kivu) in August 1994 [in French]. Ann Soc Belg Med Trop 1995;75:201-10.

[53] Bercion R, Njuimo SP, Boudjeka PM, Manirakiza A. Distribution and antibiotic susceptibility of Shigella isolates in Bangui, Central African Republic. Trop Med Int Health 2008;13:468-71.

[54] Nkuo-Akenji TK, Ntemgwa ML, Ndip RN. Asymptomatic salmonellosis and drug susceptibility in the Buea District, Cameroon. Cent Afr J Med 2001;47:254-7.

[55] Laroche R, Sirol J, Peghin M. Typhoid fever at Bangui (Centrafrican Empire). 100 cases [in French]. Bull Soc Pathol Exot Filiales 1978;71:54-63.

[56] Georges MC, Wachsmuth IK, Meunier DM, Nebout N, Didier F, Siopathis MR, et al. Parasitic, bacterial, and viral enteric pathogens associated with diarrhea in the Central African Republic. J Clin Microbiol 1984;19:571-5.

[57] Koko J, Dufillot D, Kani F, Gahouma D, Reymond-Yeni A. Salmonella meningitis in children in Libreville. Retrospective study of 9 cases [in French]. Arch Pediatr 1997;4:1175-81.

[58] Okome-Kouakou M, Bekale J, Kombila M. Salmonellosis in HIV infection in a hospital setting in Gabon [in French]. Med Trop (Mars) 1999;59:46-50. 
[59] Mashako MN, Luki N, Nsibu N, Kapongo N, Bankoto M, Mupuala M, et al. Salmonella infections in Kinshasa: the species involved and sensitivity to antibiotics [in French]. Pediatrie 1991;46:691-6.

[60] Kariuki S, Cheesbrough J, Mavridis AK, Hart CA. Typing of Salmonella enterica serotype Paratyphi $\mathrm{C}$ isolates from various countries by plasmid profiles and pulsed-field gel electrophoresis. J Clin Microbiol 1999;37:2058-60.

[61] Goossens H, Vanhoof R, de Mol P, Grados O, Ghysels G, Butzler JP. In-vitro susceptibility of salmonellae to antimicrobial agents. J Antimicrob Chemother 1984;13:559-65.

[62] Muyembe TL, Maes L, Makulu MU, Ghysels G, Vandeven J, Vandepitte J. Epidemiology and drug resistance of Salmonella infections in Kinshasa 19741975 [in French]. Ann Soc Belg Med Trop 1977;57:545-56.

[63] Georges-Courbot MC, Wachsmuth IK, Bouquety JC, Siopathis MR, Cameron DN, Georges AJ. Cluster of antibiotic-resistant Salmonella enteritidis infections in the Central African Republic. J Clin Microbiol 1990;28:771-3.

[64] Green SD, Cheesbrough JS. Salmonella bacteraemia among young children at a rural hospital in western Zaire. Ann Trop Paediatr 1993;13:45-53.

[65] Omanga U, Mashako M, Ntihinyurwa M. Indications for antibiotic therapy and stool culture during acute diarrhea in the child [in French]. Ann Pediatr (Paris) $1984 ; 31: 423-30$.

[66] Georges-Courbot MC, Baya C, Georges AJ. Serotypes, lysotypes and antibiotypes of 127 strains of Salmonella isolated in the Central African Republic: evaluation of 3378 samples taken in Bangui [in French]. Bull Soc Pathol Exot Filiales 1984;77:158-63. 
[67] Ceccarelli D, Salvia AM, Sami J, Cappuccinelli P, Colombo MM. New cluster of plasmid-located class 1 integrons in Vibrio cholerae 01 and a dfrA15 cassettecontaining integron in Vibrio parahaemolyticus isolated in Angola. Antimicrob Agents Chemother 2006;50:2493-9.

[68] Garrigue GP, Ndayo M, Sicard JM, Fonkoua MC, Lemao G, Durand JP, et al. Antibiotic resistance of strains of Vibrio cholerae eltor isolated in Douala (Cameroon) [in French]. Bull Soc Pathol Exot Filiales 1986;79:305-12.

[69] Germani Y, Quilici ML, Glaziou P, Mattera D, Morvan J, Fournier JM. Emergence of cholera in the Central African Republic. Eur J Clin Microbiol Infect Dis 1998;17:888-90.

[70] Colaert J, van Dyck E, Ursi JP, Piot P. Antimicrobial susceptibility of Vibrio cholerae from Zaire and Rwanda. Lancet 1979;2:849.

[71] Aldighieri S, Kamoso P, Suermondt G, Rugimbanya P, Ngabonziza C, Kayirangwa E. The adaptation of therapeutic standards as a function of antibiotic sensitivity of strains of Shigella spp. isolated in Rwanda in 1997 [in French]. Med Trop (Mars) 1997;57:412.

[72] Colombo MM, Mastrandrea S, Leite F, Santona A, Uzzau S, Rappelli P, et al. Tracking of clinical and environmental Vibrio cholerae 01 strains by combined analysis of the presence of toxin cassette, plasmid content and ERIC PCR. FEMS Immunol Med Microbiol 1997;19:33-45.

[73] Massenet D, Djerane L, Gamougane K, Fournier JM. Bacteriological aspects of cholera in Chad (1991 and 1994 epidemics) [in French]. Bull Soc Pathol Exot 1995;88:203-5.

[74] Ferreira E, Costa M, Vaz Pato MV. Resistance to antibiotics of Vibrio cholerae strains isolated in Angola [in French]. Pathol Biol (Paris) 1992;40:561-5. 
[75] Guevart E, Noeske J, Solle J, Mouangue A, Bikoti JM. Large-scale selective antibiotic prophylaxis during the 2004 cholera outbreak in Douala (Cameroon) [in French]. Sante 2007;17:63-8.

[76] Gangoue-Pieboji J, Koulla-Shiro S, Ngassam P, Adiogo D, Ndumbe P. Antimicrobial activity against Gram negative bacilli from Yaounde Central Hospital, Cameroon. Afr Health Sci 2006;6:232-5.

[77] Hima-Lerible H, Menard D, Talarmin A. Antimicrobial resistance among uropathogens that cause community-acquired urinary tract infections in Bangui, Central African Republic. J Antimicrob Chemother 2003;51:192-4.

[78] Jalaluddin S, de Mol P, Hemelhof W, Bauma N, Brasseur D, Hennart P, et al. Isolation and characterization of enteroaggregative Escherichia coli (EAggEC) by genotypic and phenotypic markers, isolated from diarrheal children in Congo. Clin Microbiol Infect 1998;4:213-9.

[79] Presterl E, Zwick RH, Reichmann S, Aichelburg A, Winkler S, Kremsner PG, et al. Frequency and virulence properties of diarrheagenic Escherichia coli in children with diarrhea in Gabon. Am J Trop Med Hyg 2003;69:406-10.

[80] Eggert W, Eggert S, Ferreira E, Bernardino L. The pathogen spectrum and its resistance behavior in children with urinary tract infections in Angola [in German]. Kinderarztl Prax 1992;60:46-8.

[81] Tshiendenda SA, Mutombo KL, Musuasua M, Mulowayi KW. Etude "in vitro" de la sensibilité et de la résistance de Escherichia coli et Klebsiella pneumoniae au cours de la diarrhée infantile. Congo Médical 2005;4:121-5.

[82] Osterrieth P, Doupagne P. Note sur l'incidence des différents germes dans les urinocultures. Leur sensibilité aux antibiotiques. Ann Inst Pasteur (Paris) 1956;91:187-91. 
[83] Tshiani K, Nyomba B, Bidingija M, Nkurikiyinfura JB. Infections urinaires en milieu tropical hospitalier. Une étude épidémiologique d'une bactériurie significative. Med Afr Noire 1997;26:243-9.

[84] Binda ki Muaka P, Kanda T, Ngiyulu Makuaka R, Mbensa Massabi L. Etude clinique de l'infection des voies urinaires chez l'enfant en milieu hospitalier tropical. Med Afr Noire 1990;37:19-26.

[85] Zawisza-Zenkteler W, Muyembe TL, Makulu MU. Etude de l'activité in vitro de l'association sulfamethoxazole-triméthoprime sur les bactéries isolées d'infections urinaires à Kinshasa. Med Mal Infect 1976;6:287-91.

[86] Gangoue-Pieboji J, Miriagou V, Vourli S, Tzelepi E, Ngassam P, Tzouvelekis LS. Emergence of CTX-M-15-producing enterobacteria in Cameroon and characterization of a bla 2005;49:441-3.

[87] Frank T, Arlet G, Gautier V, Talarmin A, Bercion R. Extended-spectrum $\beta$ lactamase-producing Enterobacteriaceae, Central African Republic. Emerg Infect Dis $2006 ; 12: 863-5$.

[88] Ndip RN, Dilonga HM, Ndip LM, Akoachere JF, Nkuo AT. Pseudomonas aeruginosa isolates recovered from clinical and environmental samples in Buea, Cameroon: current status on biotyping and antibiogram. Trop Med Int Health 2005;10:74-81.

[89] Nyembue DT, Tshiswaka JM, Sabue MJ, Muyunga CK. Bacteriology of chronic suppurative otitis media in Congolese children. Acta Otorhinolaryngol Belg 2003;57:205-8. 
[90] Lefevre M, Sirol J. Moraxella (Acinetobacter) and meningeal syndrome.

Isolation in Fort-Lamy (Chad) of 17 strains from the cerebrospinal fluid [in French].

Presse Med 1969;77:1899-902.

[91] World Health Organization. Meningococcal disease, Chad. Wkly Epidemiol $\operatorname{Rec} 2001 ; 76: 125-32$.

[92] Niel L, Lamarque D, Coue JC, Soares JL, Milleliri JM, Boutin JP, et al.

Chronicle of a declared meningococcal meningitis epidemic (Goma, Zaire, August 1994) [in French]. Bull Soc Pathol Exot 1997;90:299-302.

[93] Rowe AK, Schwartz B, Wasas A, Klugman KP. Evaluation of the Etest as a means of determining the antibiotic susceptibilities of isolates of Streptococcus pneumoniae and Haemophilus influenzae from children in the Central African Republic. J Antimicrob Chemother 2000;45:132-3.

[94] Wolf B, Kools-Sijmons M, Verduin C, Rey LC, Gama A, Roord J, et al. Genetic diversity among strains of Moraxella catarrhalis cultured from the nasopharynx of young and healthy Brazilian, Angolan and Dutch children. Eur J Clin Microbiol Infect Dis 2000;19:759-64.

[95] Zaidi AK, Huskins WC, Thaver D, Bhutta ZA, Abbas Z, Goldmann DA. Hospital-acquired neonatal infections in developing countries. Lancet 2005;365:1175-88.

[96] Blomberg B, Olsen BE, Hinderaker SG, Langeland N, Gasheka P, Jureen R, et al. Antimicrobial resistance in urinary bacterial isolates from pregnant women in rural Tanzania: implications for public health. Scand J Infect Dis 2005;37:262-8.

[97] Rogerie F, Vimont-Vicary P. Bacteriological study of shigellosis in the Lake Kivu area (Central Africa). Developments in the last 15 years (1968-1983) [in French]. Bull Soc Pathol Exot Filiales 1986;79:435-46. 
[98] Piot P. Eternal return... The reappearance of Shiga bacillus in Central Africa [in French]. Ann Soc Belg Med Trop 1983;63:1-3.

[99] Bogaerts J, Verhaegen J, Munyabikali JP, Mukantabana B, Lemmens P, Vandeven J, et al. Antimicrobial resistance and serotypes of Shigella isolates in Kigali, Rwanda (1983 to 1993): increasing frequency of multiple resistance. Diagn Microbiol Infect Dis 1997;28:165-71.

[100] Ndihokubwayo JB, Baribwira C, Ndayiragije A, Poste B. Antibiotic sensitivity of 299 strains of Shigella isolated in Burundi [in French]. Med Trop (Mars) 1996;56:37-40.

[101] Ries AA, Wells JG, Olivola D, Ntakibirora M, Nyandwi S, Ntibakivayo M, et al. Epidemic Shigella dysenteriae type 1 in Burundi: panresistance and implications for prevention. J Infect Dis 1994;169:1035-41.

[102] von Gottberg A, Klugman KP, Cohen C, Wolter N, de Gouveia L, du Plessis M, et al.; Group for Enteric, Respiratory and Meningeal Disease Surveillance in South Africa (GERMS-SA). Emergence of levofloxacin-non-susceptible Streptococcus pneumoniae and treatment for multidrug-resistant tuberculosis in children in South Africa: a cohort observational surveillance study. Lancet 2008;371:1108-13.

[103] Archibald LK, Reller LB. Clinical microbiology in developing countries. Emerg Infect Dis 2001;7:302-5.

[104] World Health Organization. Developing laboratory partnerships to detect infections and prevent epidemics. Lyon: WHO; 2005.

WHO/CDS/CSR/LYO/2005.19

http://www.who.int/csr/resources/publications/WHO_CDS_CSR_LYO_2005_19.p df [accessed 8 May 2009]. 
Fig. 1. Map of the Central African region, with numbers of articles retrieved per country. DRC, Democratic Republic of the Congo; CAR, Central African Republic.

\section{Table 1}

Antimicrobial resistance rates of Staphylococcus aureus, Central Africa $[10,17,22-$ $28]^{a}$

\begin{tabular}{|c|c|c|}
\hline Antimicrobial agent & $\begin{array}{l}\text { Resistance rate }(\%) \text { as } \\
\text { reported in different studies } b\end{array}$ & $\begin{array}{l}\text { Mean resistance } \\
\text { rate }(\%)^{c}\end{array}$ \\
\hline Penicillin (or ampicillin, amoxicillin) & $\begin{array}{l}0.0 \text { (2 studies), 53.6, 68.0, } \\
62.8,82.9,89.5\end{array}$ & $170 / 235(72.3 \%)$ \\
\hline Oxacillin & $\begin{array}{l}0.0 \text { (2 studies), 5.3, 21.3, } \\
35.7,63.1\end{array}$ & $130 / 469(27.7 \%)$ \\
\hline Erythromycin & $5.6,9.8,15.4$ & $23 / 151(15.2 \%)$ \\
\hline Tetracycline & $73.7-1$ & $14 / 19(73.7 \%)$ \\
\hline Trimethoprim/sulfamethoxazole & $\begin{array}{l}0.0 \text { (2 studies), } 2.8,33.3 \text {, } \\
75.0\end{array}$ & $25 / 154(16.2 \%)$ \\
\hline Chloramphenicol & 0.0 (2 studies), $5.4,10.0$ & $15 / 213(7.0 \%)$ \\
\hline Clindamycin & $8.3,35.7$ & $19 / 132(14.4 \%)$ \\
\hline Gentamicin & 0.0 (2 studies), $1.4,5.3$ & $3 / 159(1.9 \%)$ \\
\hline Fluoroquinolones & 0.0 (3 studies) & $0 / 55(0.0 \%)$ \\
\hline
\end{tabular}

${ }^{a}$ Countries and years of publication: Democratic Republic of the Congo (1954, 2001, 2004, 2004), Cameroon (1990, 2003), Congo Brazzaville (2006), Gabon (1985) and Central African Republic (2007).

${ }^{\mathrm{b}}$ Number of resistant strains/total number of strains in each study, expressed as $\%$.

${ }^{\mathrm{c}}$ Sum of all resistant organisms/sum of all organisms tested.

\section{Table 2}

Antimicrobial resistance rates of Streptococcus pneumoniae, Central Africa $[14,15,22,28-35]^{a}$ 


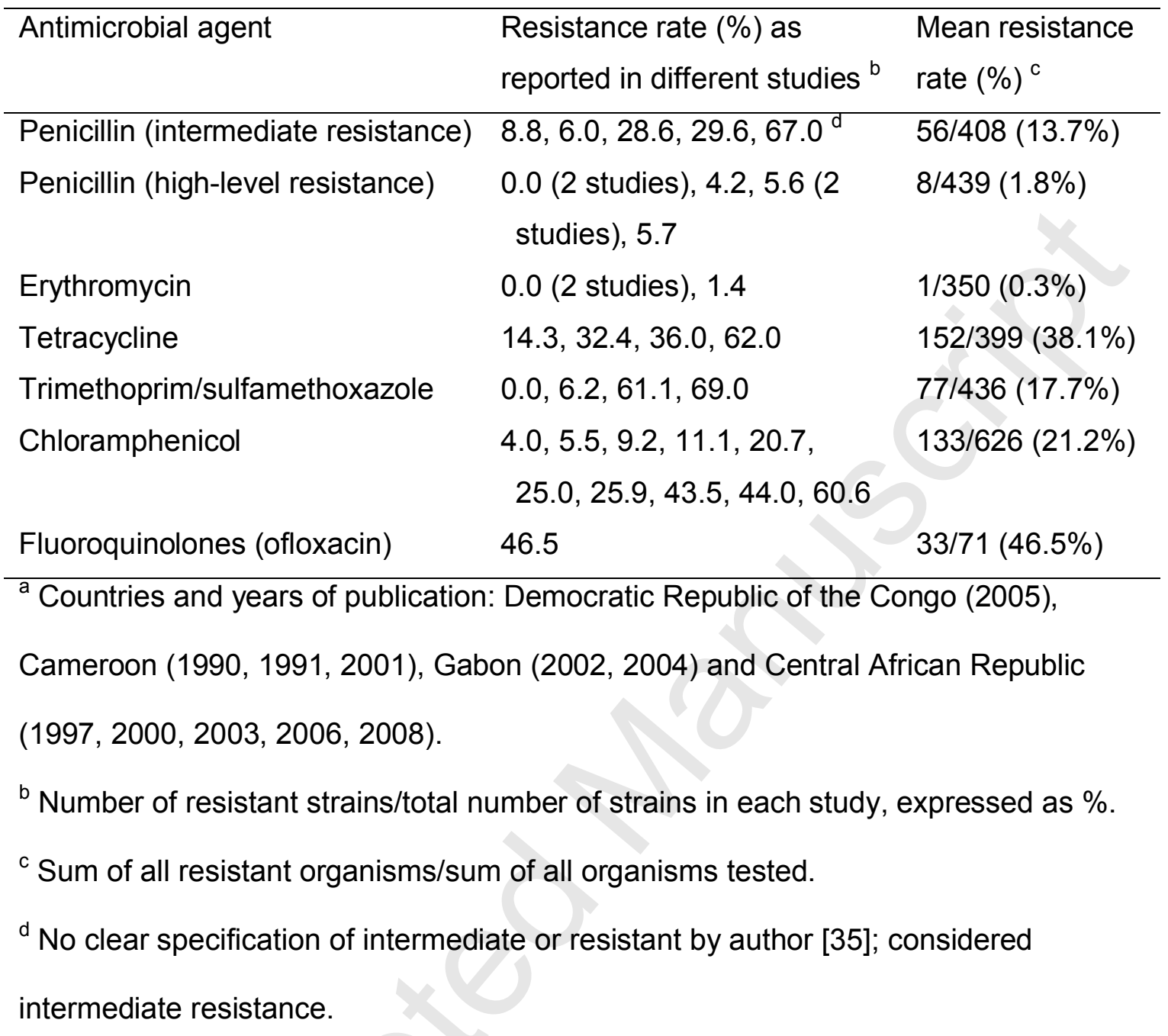

\section{Table 3}

Antimicrobial resistance rates of Salmonella enterica serovar Typhi, Central Africa $[16,18,45,49,54-62]^{\mathrm{a}}$

\begin{tabular}{lcc}
\hline Antimicrobial agent & $\begin{array}{c}\text { Resistance rate (\%) } \\
\text { as reported in } \\
\text { different studies }\end{array}$ & $\begin{array}{l}\text { Mean } \\
\text { resistance } \\
\text { rate (\%) }\end{array}$ \\
\hline Ampicillin and amoxicillin & $\begin{array}{l}\text { c.0 (5 studies), 5.5, } \\
21.0,55.5\end{array}$ & $19 / 540(3.5 \%)$ \\
Chloramphenicol & 0.0 (4 studies), 4.0, & $76 / 696$ \\
& $23.5,28.0,41.0,50$, & $(10.9 \%)$ \\
\hline
\end{tabular}


Trimethoprim/sulfamethoxazole

luoroquinolones (ofloxacin, ciprofloxacin)

Aminoglycosides

Gentamicin

Kanamycin

Streptomycin

Tobramycin

Netilmicin

Amikacin

Cephalosporins

First-generation (cefalothin, cefazolin)

Second-generation (cefamandole, cefoxitin)

Third-generation (cefotaxime, ceftriaxone)

Third-generation (ceftazidime)
0.0 (3 studies), 8.0 (2 14/496 (2.8\%) studies), 37.5

0.0 (3 studies), $98.4 \quad 8 / 177$ (4.5\%)

0.0 (5 studies), $44.4 \quad 5 / 407(1.2 \%)$

0.0 (2 studies) $\quad 0 / 106(0.0 \%)$

0.0 (2 studies) $\quad$ 0/106 $(0.0 \%)$

ND ND

ND ND

ND ND

$0.0 \quad 0 / 229(0.0 \%)$

ND

0.0 (5 studies) $\quad$ 0/168 $(0.0 \%)$

$0.0 \quad 0 / 27(0.0 \%)$

ND, no data.

${ }^{a}$ Countries and years of publication: Democratic Republic of the Congo $(1973,1977$, 1984, 1991, 1999, 2005); Gabon (1997, 1999, 2000, 2001); Central African Republic $(1978,1984)$ and Cameroon (2001).

${ }^{\mathrm{b}}$ Number of resistant strains/total number of strains in each study, expressed as \%.

${ }^{c}$ Sum of all resistant organisms/sum of all organisms tested.

\section{Table 4}

Antimicrobial resistance rates of non-typhoid Salmonella spp., Central Africa $[23,24,28,45,49,54,59,61-66]^{a}$

\begin{tabular}{|c|c|c|}
\hline Antimicrobial agent & $\begin{array}{l}\text { Resistance rate (\%) as } \\
\text { reported in different } \\
\text { studies }^{\text {b }}\end{array}$ & $\begin{array}{l}\text { Mean } \\
\text { resistance rate } \\
(\%)^{c}\end{array}$ \\
\hline Ampicillin and amoxicillin & $\begin{array}{l}\text { 5.4, 62.9, 69.0, 92.7, } \\
100 \text { (3 studies) }\end{array}$ & $\begin{array}{r}271 / 430 \\
(63.0 \%)\end{array}$ \\
\hline
\end{tabular}




\begin{tabular}{llc}
\hline Chloramphenicol & $5.7,31.3,35.4,54.3$, & $239 / 557$ \\
& $67,75,100(2$ & $(42.9 \%)$ \\
& studies) & \\
& $0.0,1.1,7.0,16.0$, & $53 / 363$ \\
Trimethoprim/sulfamethoxazole & $42.9,53.9,100$ & $(14.6 \%)$ \\
& $0.0(2$ studies), 1.6, & $23 / 137$ \\
Fluoroquinolones (ofloxacin, ciprofloxacin) & 85.7 & $(16.8 \%)$ \\
& & \\
Aminoglycosides & $0.0(3$ studies), 15.0 & $11 / 284(3.9 \%)$ \\
Gentamicin & 54.4 & $60 / 110$ \\
Kanamycin & & $(54.5 \%)$ \\
& $86.2,100$ & $107 / 122$ \\
Streptomycin & & $(87.7 \%)$ \\
& $\mathrm{ND}$ & $\mathrm{ND}$ \\
Tobramycin & $\mathrm{ND}$ & $\mathrm{ND}$ \\
Netilmicin & $\mathrm{ND}$ & $\mathrm{ND}$ \\
Amikacin & & \\
Cephalosporins & 3.3 & $4 / 122(3.3 \%)$ \\
First-generation (cefalothin, cefazolin) & 100 & $26 / 26(100 \%)$ \\
Second-generation (cefuroxime) & $0.0(3$ studies) & $0 / 151(0.0 \%)$ \\
Third-generation (cefotaxime, ceftriaxone) & $0 / 75(0.0 \%)$ \\
Third-generation (ceftazidime) & 0.0 &
\end{tabular}

ND, no data.

${ }^{a}$ Countries and years of publication: Democratic Republic of the Congo (1973, 1977, 1984, 1984, 1991, 2001, 2004, 2005), Central African Republic (1984, 1990, 2008), Gabon (1986) and Cameroon (2001)

${ }^{\mathrm{b}}$ Number of resistant strains/total number of strains in each study, expressed as \%.

${ }^{\mathrm{c}}$ Sum of all resistant organisms/sum of all organisms tested.

\section{Table 5}

Antimicrobial resistance rates of Escherichia coli, Central Africa $[23,24,25,44,76-85]$ 


\begin{tabular}{|c|c|c|}
\hline Antimicrobial agent & $\begin{array}{l}\text { Resistance rate (\%) } \\
\text { as reported in } \\
\text { different studies }\end{array}$ & $\begin{array}{l}\text { Mean } \\
\text { resistance } \\
\text { rate }(\%)^{\mathrm{c}}\end{array}$ \\
\hline Ampicillin and amoxicillin & $\begin{array}{l}\text { Median } 82.1 \text { (range } \\
64.0-100 \text { ) in } 12 \\
\text { studies }\end{array}$ & $\begin{array}{c}2184 / 2834 \\
(77.1 \%)\end{array}$ \\
\hline Chloramphenicol & $\begin{array}{l}\text { Median } 64.5 \text { (range } \\
\text { 15.0-100) in } 7 \\
\text { studies }\end{array}$ & $\begin{array}{c}1753 / 2363 \\
(74.2 \%)\end{array}$ \\
\hline Nitrofurantoin (urinary tract isolates) & $6.3,9.4,21.5$ & $\begin{array}{c}115 / 1161 \\
(9.9 \%)\end{array}$ \\
\hline Trimethoprim (urinary tract isolates) & 58.0 & $33 / 57(57.9 \%)$ \\
\hline Trimethoprim/sulfamethoxazole & $\begin{array}{l}\text { Median } 63.3 \text { (range } \\
0.0-87.1 \text { ) in } 11 \\
\text { studies }\end{array}$ & $\begin{array}{c}1264 / 1839 \\
(68.7 \%)\end{array}$ \\
\hline Amoxicillin/clavulanic acid & $0.0,28.0,57.0$ & $\begin{array}{r}222 / 349 \\
(63.6 \%)\end{array}$ \\
\hline Fluoroquinolones (ofloxacin, ciprofloxacin) & $\begin{array}{l}0.0 \text { (2 studies), 9.0, } \\
\text { 10.0, } 43.5\end{array}$ & $\begin{array}{l}52 / 415 \\
(12.5 \%)\end{array}$ \\
\hline \multicolumn{3}{|l|}{ Aminoglycosides } \\
\hline Gentamicin & $\begin{array}{l}0.0 \text { (2 studies), 6.0 } \\
\text { 11.2, 16.0, 20.0 } \\
21.0,91.1\end{array}$ & $\begin{array}{r}266 / 1405 \\
(18.9 \%)\end{array}$ \\
\hline Tobramycin & 6.0 & $10 / 174(5.7 \%)$ \\
\hline Netilmicin & 4.0 & $7 / 174(4.0 \%)$ \\
\hline Amikacin & 0.0 & $0 / 174(0.0 \%)$ \\
\hline \multicolumn{3}{|l|}{ Cephalosporins } \\
\hline First-generation (cefalothin, cefazolin) & $0.0,56.0,59.0$ & $\begin{array}{l}193 / 349 \\
(55.3 \%)\end{array}$ \\
\hline Second-generation (cefamandole, cefoxitin) & $87.0,9.0$ & $\begin{array}{l}22 / 220 \\
(10.0 \%)\end{array}$ \\
\hline Third-generation (cefotaxime, ceftriaxone) & 0.0 (4 studies), 9.0 & $15 / 500(3.0 \%)$ \\
\hline Third-generation (ceftazidime) & $0.0,5.0$ & $8 / 337(2.4 \%)$ \\
\hline
\end{tabular}


${ }^{a}$ Countries and years of publication: Democratic Republic of the Congo $(1958,1976$, 1979, 1990, 1998, 2001, 2004, 2005), Cameroon (1999, 2006), Angola (1992),

Gabon (1985, 2003) and Central African Republic (2003).

${ }^{b}$ Number of resistant strains/total number of strains in each study, expressed as \%.

${ }^{c}$ Sum of all resistant organisms/sum of all organisms tested.

\section{Table 6}

Antimicrobial resistance rates of Klebsiella spp., Central Africa

$[11,23,24,25,33,76,80,81,83-85]^{a}$

\begin{tabular}{lll}
\hline Antimicrobial agent & $\begin{array}{l}\text { Resistance rate (\%) as } \\
\text { reported in different } \\
\text { studies }^{\text {b }}\end{array}$ & $\begin{array}{l}\text { Mean } \\
\text { resistance rate } \\
(\%)^{c}\end{array}$ \\
\hline Ampicillin and amoxicillin & Median 97.6 (range & $679 / 1591$ \\
& $6.0-100)$ in 10 & $(42.7 \%)$ \\
Chloramphenicol & studies & \\
& Median 42.6 (range & $631 / 1462$ \\
Trimethoprim/sulfamethoxazole & $25.0-95.7)$ in 6 & $(43.2 \%)$ \\
& studies & \\
Amoxicillin/clavulanic acid & Median $84.2($ range & $1159 / 1444$ \\
Fluoroquinolones (ofloxacin) & $12.7-100)$ in 10 & $(80.3 \%)$ \\
Aminoglycosides (gentamicin) & studies & \\
Cephalosporins & $36.3,65.0$ & $9 / 17(52.9 \%)$ \\
First-generation (cefalexin, cefazolin) & $0.0,2.0,4.5,42.9$ & $10 / 136(7.4 \%)$ \\
Second-generation (cefoxitin, cefuroxime) & $4.5,16.0,85.7$ & $158 / 331$ \\
Third-generation (cefotaxime) & $0.0,7.5,29.9$ & $(47.7 \%)$ \\
\hline
\end{tabular}


${ }^{a}$ Countries and years of publication Democratic Republic of the Congo $(1976,1979$, 1990, 2001, 2004, 2005), Cameroon (2001, 2006), Angola (1992) and Gabon (1985, 2004).

${ }^{\mathrm{b}}$ Number of resistant strains/total number of strains in each study, expressed as \%.

${ }^{c}$ Sum of all resistant organisms/sum of all organisms tested.

\section{Table 7}

Antimicrobial resistance rates of Pseudomonas aeruginosa, Central Africa $[25,76,88,89]^{a}$

\begin{tabular}{lll}
\hline Antimicrobial agent & $\begin{array}{l}\text { Resistance rate (\%) as } \\
\text { reported in different } \\
\text { studies }^{\text {b }}\end{array}$ & $\begin{array}{l}\text { Mean } \\
\text { resistance rate } \\
(\%)^{c}\end{array}$ \\
\hline Piperacillin & 54.0 & $36 / 67(53.7 \%)$ \\
Fluoroquinolones (ofloxacin, ciprofloxacin) & $0.0,2.0,33.0$ & $23 / 148$ \\
& & $(15.5 \%)$ \\
Aminoglycosides & $43.4,51.0,66.7,93.0$ & $191 / 266$ \\
Gentamicin & & $(71.8 \%)$ \\
Tobramycin & $44.0,58.8$ & $60 / 118$ \\
Netilmicin & & $(50.8 \%)$ \\
Amikacin & 19.6 & $10 / 51(19.6 \%)$ \\
Ceftazidime & 9.8 & $5 / 51(9.8 \%)$ \\
Imipenem & $28.8,37.3$ & $38 / 118$ \\
\hline
\end{tabular}

${ }^{\mathrm{a}}$ Countries and years of publication: Democratic Republic of the Congo (2003),

Cameroon (2005, 2006) and Gabon (1985).

${ }^{b}$ Number of resistant strains/total number of strains in each study, expressed as \%. 
${ }^{\mathrm{c}}$ Sum of all resistant organisms/sum of all organisms tested. 


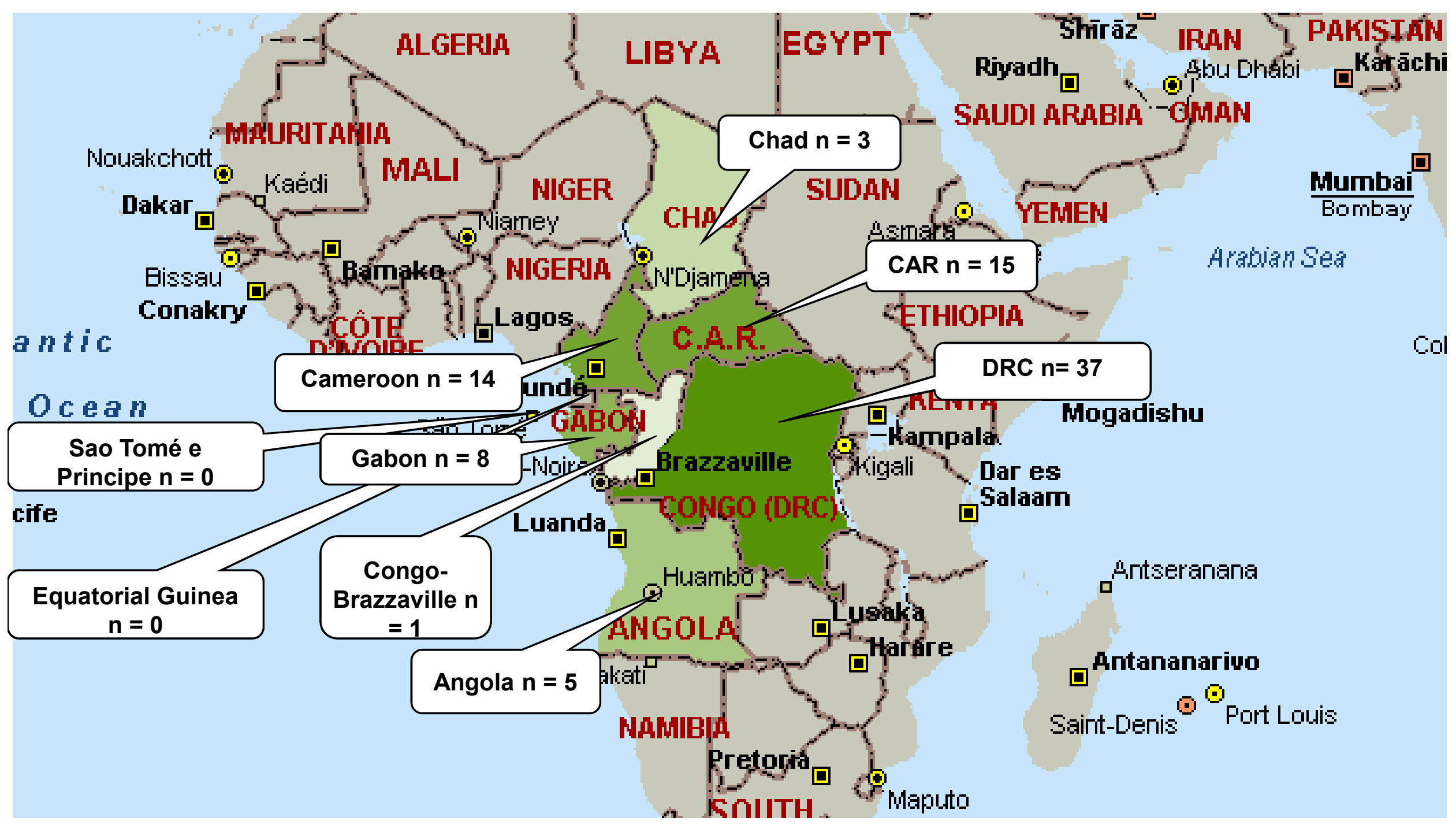

